\title{
PENGEMBANGAN KOMIK CERITA RAKYAT ASAL USUL SUNGAI SORAI UNTUK SISWA KELAS V SEKOLAH DASAR
}

\author{
${ }^{1}$ Muharramah Suwitri, ${ }^{2}$ Otang Kurniaman, ${ }^{3}$ Munjiatun \\ ${ }^{1,2,3}$ Universitas Riau, Indonesia. \\ Email:' ${ }^{m}$ muharramah.suwitri2338@ student.unri.ac.id, ${ }^{2}$ otang.kurniaman@lecturer.unri.ac.id, \\ ${ }^{3}$ munjiatun@lecturer.unri.ac.id
}

\begin{abstract}
This study aims to produce a folklore comic about the origin of the sungai sorai for fifth grade elementary school students and to determine the feasibility of the sungai sorai origin folklore comic for fifth grade elementary school students. This study uses the Research and Development $(R \& D)$ method or research and development using the Four-D model (Define, Design, Develop, Disseminate). Data collection techniques used are interviews, questionnaires and written tests. The feasibility of folklore comics was obtained from the results of validation, product trials and written tests. Validation is carried out by design experts, linguists and practitioners. The product trials conducted were limited to only 10 students. The written test used is in the form of objective questions to determine students' knowledge and understanding of folklore comics. The results showed that the validation of design experts obtained an assessment with a very valid category. In validation, linguists obtained an assessment with a very valid category. The next validation is practitioner validation with a very valid category. The product trial used is a limited product trial with the category of student response assessment which is very good. The student's written test in the form of objective questions about folklore comics received an assessment in the very good category. The results of this development research indicate that the folklore comic "The Origin of the Sungai Sorai" is very suitable for use for fifth grade elementary school students.
\end{abstract}

Keywords: Comics, Folklore, Origin of the Sungai Sorai.

\begin{abstract}
Penelitian ini bertujuan untuk menghasilkan suatu komik cerita rakyat asal usul sungai sorai untuk siswa kelas V Sekolah Dasar dan untuk mengetahui kelayakan komik cerita rakyat asal usul sungai sorai untuk siswa kelas V Sekolah Dasar. Penelitian ini menggunakan metode Research and Development (R\&D) atau penelitian dan pengembangan dengan menggunakan model Four-D (Define, Design, Develop, Disseminate). Teknik pengumpulan data yang digunakan yaitu wawancara, angket dan tes tertulis. Kelayakan komik cerita rakyat diperoleh dari hasil validasi, uji coba produk dan tes tertulis. Validasi dilakukan oleh ahli desain, ahli bahasa dan praktisi. Uji coba produk yang dilakukan terbatas yaitu hanya 10 orang siswa. Tes tertulis yang digunakan berupa soal objektif untuk mengetahui pengetahuan dan pemahaman siswa terhadap komik cerita rakyat. Hasil penelitian menunjukkan bahwa validasi ahli desain memperoleh penilaian dengan kategori sangat valid. Pada validasi ahli bahasa memperoleh penilaian dengan kategori sangat valid. Validasi selanjutnya yaitu validasi praktisi dengan kategori sangat valid. Uji coba produk yang digunakan yaitu uji coba produk terbatas dengan kategori penilaian respon siswa yaitu sangat baik. Tes tertulis siswa berupa soal objektif mengenai komik cerita rakyat memperoleh penilaian dengan kategori sangat baik. Hasil penelitian pengembangan ini menunjukkan bahwa komik cerita rakyat "Asal Usul Sungai Sorai" sangat layak digunakan untuk siswa kelas V Sekolah Dasar.
\end{abstract}

Kata Kunci: Komik, Cerita Rakyat, Asal Usul Sungai Sorai.

\section{PENDAHULUAN}

Perkembangan ilmu pengetahuan dan teknologi saat ini berkembang sangatlah pesat, hal ini tentunya mempengaruhi kehidupan manusia, terutama dalam dunia pendidikan. Kemajuan suatu bangsa dapat dilihat dari dunia pendidikannya, salah satunya dalam proses belajar. (Maulida, 2018) Pemahaman bahan bacaan tidak bisa dilepaskan dari proses belajar. Proses belajar suatu bacaan dapat dilihat dari nilai-nilai 
yang diperoleh siswa. Pemahaman makna dari suatu bacaan merupakan tujuan utama dari aktivitas membaca. Dengan kata lain, ketika membaca, pembaca juga harus dapat memahami makna dan isi dari bacaan tersebut. Oleh karena itu media pembelajaran diperlukan sebagai sarana penyampaian pesan dari guru pada siswa. Penyampaian suatu konsep pada siswa akan tersampaikan dengan baik jika konsep tersebut mengharuskan siswa terlibat langsung di dalamnya bila dibandingkan dengan konsep yang hanya melibatkan siswa untuk mengamati saja, dengan penggunaan media pembelajaran diharapkan dapat memberikan pengalaman belajar yang lebih konkret kepada siswa dan dapat meningkatkan keaktifan siswa dalam pembelajaran (Ramadan, Kurniaman \& Noviana, 2013)

Salah satu usaha guru untuk meningkatkan pemahaman siswa adalah dengan mengembangkan bahan bacaan untuk media pembelajaran. Masih minim ditemukan bahan bacaan yang dapat meningkatkan pemahaman siswa. Seiring dengan berjalannya waktu banyak pembaharuan-pembaharuan di bidang teknologi yang menunjukkan bahwa pendidikan mengalami perkembangan yang sangat pesat. Sehingga dengan perkembangan teknologi tersebut, guru diharapkan dapat meningkatkan kualitas pembelajaran dengan bahan bacaan yang menarik untuk meningkatkan minat dan pemahaman siswa, salah satunya adalah dengan menggunakan media komik. Komik adalah suatu kartun yang mengungkapkan suatu karakter yang memerankan suatu cerita dalam urutan yang erat, dihubungkan dengan gambar dan dirancang untuk memberikan hiburan kepada para pembaca (Hidayah \& Rifky, 2017).

Cerita komik yang sangat imajinatif dengan dukungan gambar yang menarik serta komunikasi yang lugas membuat komik begitu diminati untuk dikonsumsi dikalangan anak-anak (Utariyanti, Wahyuni \& Zaenab, 2015). Komik yang mengandung pesan-pesan dan dapat dikaitkan dengan materi pembelajaran salah satunya adalah komik cerita rakyat. Tokoh-tokoh yang diceritakan dalam cerita rakyat ini berkaitan dengan budaya yang ada di dalam negeri, sehingga siswa diharapkan dapat melestarikan dan mengembangkan budaya lokal. Dilihat dari perkembangan globalisasi saat ini dimana generasi penerus bangsa lebih mengetahui budaya luar dibandingkan dengan budaya dalam negeri. Romario dan Rahmatsyam (2014) mengatakan generasi muda lebih mengenal tokoh-tokoh luar dari pada tokoh-tokoh dalam negeri, mereka lebih dekat dengan Naruto, dari pada dengan Gatotkaca, mereka lebih mengenal Cinderella dari pada dengan Bawang Merah Bawang Putih. Cerita asal usul suatu tempat bahkan sekarang ini tidak diketahui oleh peserta didik, karena tidak adanya media menarik yang menyajikan cerita tersebut, sehingga ceritanya hilang begitu saja. Salah satunya adalah asal usul Sungai Sorai yang diceritakan hanya pada buku tanpa gambar, sehingga tidak menarik peserta didik untuk membacanya.

Mengingat agar tidak hilangnya cerita rakyat yang mengandung pesan-pesan yang sangat bermanfaat bagi penerus bangsa, sesuai dengan pendapat Sumayana (2017) sebagai genre sastra lisan cerita rakyat memiliki manfaat yang banyak bagi siswa maupun masyarakat pendukungnya. Di dalamnya terkandung nilai-nilai pendidikan maupun nilai-nilai moral yang bermanfaat. Maka diperlukanlah suatu media untuk melestarikan cerita rakyat tersebut. Perkembangan teknologi saat sekarang ini diharapkan dapat digunakan sebagai salah satu cara untuk menyajikan media komik cerita rakyat ini agar dapat disajikan secara menarik, sehingga dapat meningkatkan pemahaman siswa agar lebih mengetahui pesan-pesan, tokoh-tokoh, dan cerita rakyat yang ada di daerahnya. 


\section{METODE PENELITIAN}

Jenis penelitian yang dilakukan yaitu penelitian dan pengembangan (Research and Development). Penelitian ini digunakan apabila penelitian bermaksud menghasilkan produk tertentu, dan sekaligus menguji keefektifan produk tersebut (Sugiyono, 2018). Desain penelitian menggunakan model Four-D (Define, Design, Develop, Disseminate) sesuai dengan yang telah dikembangkan oleh Thiagarajan. Model pengembangan ini dipilih karena penelitian ini akan menghasilkan produk berupa komik. Produk yang dikembangkan ini kemudian akan diuji kelayakannya dengan validasi produk dengan tujuan mengetahui kelayakan dari komik cerita rakyat. Prosedur pengembangan komik dengan menggunakan model Four-D dilakukan dengan 4 tahap, yaitu: tahap pendefinisian, tahap perancangan, tahap pengembangan dan penyebaran.

Jenis data yang digunakan dalam penelitian ini adalah data kualitatif dan kuantitatif. Data kualitatif yaitu untuk memperoleh informasi mengenai cerita rakyat "Asal Usul Sungai Sorai" dari narasumber melalui kegiatan wawancara Sedangkan data kuantitatif yaitu untuk memperoleh data dalam bentuk skor dari penilaian oleh validator (ahli desain, ahli bahasa, praktisi) untuk mengetahui kelayakan produk dan penilaian siswa terhadap

Teknik pengumpulan data dalam penelitian ini berupa wawancara, angket dan tes tertulis. Menganalisis data kuantitatif dari instrumen penelitian validasi ahli desain, bahasa, praktisi dan respon siswa digunakan dengan teknik perhitungan statistik yaitu skala Likert dengan skor 1-4. Berikut ketentuan pemberian skor.

Tabel 1. Ketentuan Pemberian Skor

\begin{tabular}{cc}
\hline Skor & Kategori \\
\hline 4 & SS (Sangat Setuju) \\
\hline 3 & S (Setuju) \\
\hline 2 & KS (Kurang Setuju) \\
\hline 1 & TS (Tidak Setuju) \\
\hline
\end{tabular}

(Sumber: Modifikasi Sugiyono, 2018:94)

Setelah memperoleh penilaian selanjutnya yaitu menentukan persentase skor penilaian yang diperoleh menggunakan rumus sebagai berikut.

Persentase $=\frac{\text { Skor yang diperoleh }}{\text { skor maksimum }} \times 100 \%$

Adapun persentase nilai validasi, respon siswa dan tes tertulis siswa berdasarkan ketentuan sebagai berikut:

Tabel 2. Kategori Validasi Produk

\begin{tabular}{cc}
\hline Rata-rata Persentase $(\boldsymbol{\%})$ & Kategori \\
\hline $76-100$ & Sangat Valid \\
\hline $51-75$ & Valid \\
\hline $26-50$ & Kurang Valid \\
\hline $0-25$ & Tidak Valid \\
\hline
\end{tabular}


Tabel 3. Kategori Respon Siswa

\begin{tabular}{cc}
\hline Rata-rata Persentase $(\boldsymbol{\%})$ & Kategori \\
\hline $76-100$ & Sangat Baik \\
\hline $51-75$ & Baik \\
\hline $26-50$ & Kurang Baik \\
\hline $0-25$ & Tidak Baik \\
\hline
\end{tabular}

Tabel 4. Kategori Tes Tertulis

Rata-rata Persentase (\%) Kategori

\begin{tabular}{cc}
\hline $76-100$ & Sangat Baik \\
\hline $51-75$ & Baik \\
\hline $26-50$ & Kurang Baik \\
\hline $0-25$ & Tidak Baik \\
\hline
\end{tabular}

\section{HASIL DAN PEBAHASAN}

Hasil

Komik cerita rakyat "Asal Usul Sungai Sorai" dikembangkan dengan menggunakan model Four-D yang memiliki 4 tahap utama yaitu, Define (pendefinisian), Design (perancangan), Develop (pengembangan) dan Disseminate (penyebaran). Berikut merupakan pelaksanaan penelitian pengembangan komik cerita rakyat "Asal Usul Sungai Sorai" untuk siswa kelas V Sekolah Dasar.

\section{a. Define (pendefinisian)}

Tahap ini terdiri dari analisis awal dan analisi cerita.

1) Analisisi Awal

Pada tahap ini dilakukan analisis awal yaitu menganalisis cerita rakyat Rokan Hulu tepatnya di Desa Muara Rumbai. Salah satu cerita rakyatnya adalah asal usul Sungai Sorai, banyak pesan-pesan baik yang tedapat di dalam cerita. Cerita rakyat "Asal Usul Sungai Sorai" ini diketahui setelah membaca digital book "Lagenda Sungai Tapung Kumpulan Cerita Rakyat Rokan Hulu” penerbit Dr. Dendy Sugono terbit tahun 2008 (Sugono, 2008). Cerita rakyat "Asal Usul Sungai Sorai" disajikan pada digital book menampilkan cerita berupa tulisan saja tanpa adanya gambar, hal ini tentunya membuat pembaca terutama siswa SD merasa bosan untuk membaca ceritanya.

Salah satu upaya yang dapat dilakukan untuk melestarikan cerita rakyat yang merupakan budaya lokal ini adalah dengan penambahan bahan bacaan selain digital book. Penambahan bahan bacaan bisa berupa komik. Komik ini membuat cerita rakyat menjadi sajian yang menarik karena dengan adanya gambar. Sekolah Dasar masih sangat minim bahan bacaan, sehingga diperlukan bahan bacaan yang dapat meningkatkan minat dan pemahaman siswanya, salah satunya komik cerita rakyat. Dengan komik cerita rakyat ini selain sebagai bahan bacaan variasi baru, juga sebagai media untuk melestarikan cerita rakyat yang mulai hampir hilang kepada generasi penerus bangsa.

2) Analisi Cerita

Analisis cerita dilakukan setelah mengetahui cerita rakyat asal usul Sungai Sorai melalui digital book dan wawancara. Pada masyarakat Muara Rumbai cerita ini 
merupakan sastra lisan yang berkembang di masyarakatnya. Hal ini diketahui dari wawancara yang dilakukan peneliti pada sekretaris Dusun Sejati, nenek Banun, nenek Jana, dan kakek Sembai tetua yang tinggal di Dusun Sejati. Tujuan dari wawancara ini adalah untuk mengetahui cerita rakyat "Asal Usul Sungai Sorai" yang berkembang di kalangan masyarakatnya dan dari wawancara ini peneliti juga dapat menyesuaikan cerita yang didapatkan dari digital book dengan dari narasumber.

Setelah wawancara, analisis cerita diawali dengan penentuan tokoh beserta karakternya, tempat dan waktu, alur cerita, gambar sketsa sesuai alur cerita yang akan dikembangkan menjadi sebuah komik.

\section{b. Design (perancangan)}

Tahap ini dilakukan dengan merancang bagaimana penyajian komik cerita rakyat asal usul Sungai Sorai yang disesuaikan dengan digital book dan wawancara yang dilakukan pada tahap pendefinisian. Produk yang dihasilkan pada tahap ini adalah komik cerita rakyat asal usul Sungai Sorai sebagai bahan bacaan untuk siswa kelas V SD. Pada tahap perancangan komik dilakukan kegiatan sebagai berikut:

1) Tulis Dialog Sesuai Dengan Cerita

Setelah mengetahui cerita rakyat Asal Usul Sungai Sorai dari digital book dan wawancara dilakukan menulis dialog sesuai dengan cerita yang telah didapatkan. Penulisan ini diawali dengan membuat alur cerita setiap adegan yang disusun dengan panel-panel yang saling berkaitan satu sama lain. Panel ini terdiri dari prolog dan dialog antar tokoh yang menceritakan setiap kejadian.

2) Tokoh/Karakter

Hasil analisi cerita rakyat yang telah dilakukan terdapat tokoh-tokoh yang berperan di dalam cerita rakyat tersebut, adapun tokohnya adalah Mak Sorai, Somat, Ongkak, Radang, Ate, Itam, Iyai, penduduk. Tokoh-tokoh didesain sesuai dengan karakternya masing-masing. Pada tokoh Mak Sorai menggambarkan sosok orang tua dengan menggunakan jilbab penutup kepala. Pada tokoh anak-anak menggambarkan sosok anak yang beranjak remaja.

3) Komik

Tahap perancangan komik ini menggunakan gambar manual sebagai pola yang kemudian agar komik menjadi menarik dengan berbagai warna digunakan aplikasi Autodesk SketchBook. Aplikasi ini digunakan karena memudahkan peneliti untuk membuat gambar sesuai dengan yang diinginkan.

a) Teknik melukis manual menggunakan pensil yang digambar langsung pada HVS ukuran A4 ini digunakan sebagai pola gambar komik, ukuran HVS A4 ini digunakan agar menggambar dapat dilakukan dengan baik sesuai dengan yang diinginkan.

b) Teknik pewarnaan menggunakan aplikasi Autodesk SketchBook, yang diawali dengan penebalan pola yang kemudian dilanjutkan dengan pewarnaan keseluruhan pola pada komik.

c) Tembuatan sampul komik, sampul komik terdiri dari judul cerita dan nama penulis, serta sampul komik juga menggambarkan tokoh utama dan gambar yang mewakili isi cerita.

d) Cerita rakyat "Asal Usul Sungai sorai" dijadikan bagian-bagian pendek yang menggambarkan kejadian, dimana dan kapan cerita tersebut. Komik ini terdiri dari 2-4 panel, di dalam panel terdapat teks prolog dan teks dialog yang menceritakan kejadian yang sedang terjadi. 
e) Menentukan jenis tulisan pada judul komik menggunakan tulisan Cooper Black, pada teks prolog dan teks dialog menggunakan tulisan Comic Sans MS. Tulisan ini digunakan agar tampilan komik menarik untuk dibaca.

f) Menyesuaikan ukuran tulisan yang digunakan pada teks prolog dan teks dialog berukuran 10.

c. Develop (pengembangan)

1) Validasi Komik

Tahap validasi ini merupakan tahap untuk melakukan studi kelayakan terhadap produk yang akan dikembangkan. Validasi komik ini dilakukan oleh ahli desain, ahli bahasa, dan validator praktisi. Validator terdiri dari 1 validator ahli desain, 1 validator ahli bahasa dan 3 validator praktisi yang menilai kelayakan produk komik cerita rakyat "Asal Usul Sungai Sorai".

Tabel 5. Rekapitulasi hasil validasi produk

\begin{tabular}{cccl}
\hline No & Validator & Persentase (\%) & Kategori \\
\hline 1 & Validasi Ahli Desain Draft 1 & $65,18 \%$ & Valid \\
\hline 2 & Validasi Ahli Desain Draft 2 & $96,43 \%$ & Sangat Valid \\
\hline 3 & Validasi Ahli Bahasa Draft 1 & $92,71 \%$ & Sangat Valid \\
\hline 4 & Validasi Ahli Bahasa Draft 2 & $100 \%$ & Sangat Valid \\
\hline 5 & Validasi Praktisi Desain & $97,03 \%$ & Sangat Valid \\
\hline 6 & Validasi Praktisi Bahasa & $96,53 \%$ & Sangat Valid \\
\hline
\end{tabular}

Komik yang telah di validasi kemudian di revisi sesuai saran dan masukan dari validator. Hasil akhir produk yang telah divalidasi dan direvisi memperoleh penilaian sangat valid. Hal ini menandakan bahwa produk sudah layak untuk diuji cobakan.

2) Uji Coba Produk

Pada tahap ini dilakukan uji coba produk komik terbatas untuk memperoleh informasi mengenai respon siswa setelah menggunakan rancangan produk komik cerita rakyat "Asal Usul Sungai Sorai" yang dikembangkan. Peneliti melakukan uji coba produk terbatas kepada siswa kelas V SD yang berjumlah 10 orang. Berikut adalah data respon siswa terhadap komik cerita rakyat "Asal Usul Sungai Sorai".

Tabel 6. Data Respon Siswa pada Uji Coba Produk Terbatas

\begin{tabular}{cccl}
\hline No & Indikator & Persentase $(\boldsymbol{\%})$ & Kategori \\
\hline 1 & Penggunaan Gambar & $100 \%$ & Sangat Baik \\
\hline 2 & Penggunaan Warna & $100 \%$ & Sangat Baik \\
\hline 3 & Penggunaan Huruf & $100 \%$ & Sangat Baik \\
\hline 4 & Penggunaan Bahasa & $100 \%$ & Sangat Baik \\
\hline
\end{tabular}




\begin{tabular}{cccc}
\hline 5 & Isi Cerita & $98,75 \%$ & Sangat Baik \\
\hline 6 & Alur Cerita & $92,5 \%$ & Sangat Baik \\
\hline 7 & Manfaat Cerita & $95 \%$ & Sangat Baik \\
\hline & Rata-rata Skor & $\mathbf{9 8 , 0 4 \%}$ & Sangat Baik \\
\hline
\end{tabular}

Berdasarkan hasil data respon siswa terhadap komik cerita rakyat "Asal Usul Sungai Sorai" yang dikembangkan oleh peneliti diperoleh rata-rata skor 98,04\% dengan kategori sangat baik. Berdasarkan hasil tersebut secara keseluruhan komik cerita rakyat "Asal Usul Sungai Sorai" yang dikembangkan oleh peneliti mendapat respon yang sangat baik dari siswa yang menggunakan produk ini.

3) Tes Tertulis Siswa

Tahap ini juga dilakukan tes pengetahuan dan pemahaman siswa terhadap komik cerita rakyat "Asal usul Sungai sorai" untuk mengukur kemampuan siswa setelah membaca komik cerita rakyat. Tes ini dilakukan dengan memberikan 10 soal objektif. Hasil dari tes pengetahuan dan pemahaman siswa terhadap komik cerita rakyat "Asal usul Sungai sorai" sebagai berikut:

Tabel 7. Hasil Tes Pengetahuan dan Pemahaman Siswa

\begin{tabular}{cccc}
\hline Siswa & Nilai & Persentase & Kategori \\
\hline Siswa 1 & 80 & & \\
\hline Siswa 2 & 90 & & \\
\hline Siswa 3 & 90 & & \\
\hline Siswa 4 & 100 & & Sangat Baik \\
\hline Siswa 5 & 70 & $91 \%$ & \\
\hline Siswa 6 & 80 & & \\
\hline Siswa 7 & 100 & & \\
\hline Siswa 8 & 100 & & \\
\hline Siswa 9 & 100 & & \\
\hline Siswa10 & 100 & &
\end{tabular}

Hasil tes pengetahuan dan pemahaman siswa setelah membaca komik cerita rakyat "Asal Usul Sungai Sorai" diperoleh pesentase 91\% dengan kategori sangat baik. Berdasarkan hasil tersebut, komik cerita rakyat "Asal Usul Sungai Sorai" yang dikembangkan peneliti dapat memberikan pengetahuan dan pemahaman yang sangat baik kepada siswa.

\section{d. Disseminate (penyebaran)}

Pada penelitian ini tahap penyebaran dilakukan dengan cara FGD (Focus Group Discussion) atau diskusi kelompok terfokus dengan beberapa ahli. FGD ini dilakukan peneliti pada hari Rabu, 24 Maret 2021 di SD dengan 5 orang guru SD. Hasil diskusi mengenai produk ini adalah dapat meningkatkan minat siswa untuk membaca karena terdapat gambar-gambar yang disajikan dengan teks bacaan, siswa dapat lebih mudah memahami cerita karena menggunakan bahasa sehari-hari dan dengan sajian menarik berupa komik, melalui komik cerita rakyat ini siswa dapat mengetahui cerita rakyat yang ada di daerahnya sebagai cara untuk melestarikan cerita rakyat kepada generasi penerus bangsa, komik ini juga tentunya akan menjadi bahan bacaan yang bagus untuk dibaca oleh siswa karena terdapat pesan-pesan baik yang bisa diterapkan di kehidupan, dan komik cerita rakyat ini juga menjadi bahan bacaan baru bagi sekolah untuk meningkatkan gerakan literasi sekolah. 


\section{Pembahasan}

Komik adalah gambar-gambar dan lambang-lambang lain yang ter-jukstaposisi (berdekatan, bersebelahan) dalam urutan tertentu untuk menyampaikan informasi dan atau mencapai tanggapan estetis dari pembaca (McCloud, 2002:9). Cerita komik yang sangat imajinatif dengan dukungan gambar yang menarik serta komunikasi yang lugas membuat komik begitu diminati untuk dikonsumsi dikalangan anak-anak (Utariyanti, Wahyuni \& Zaenab, 2015). Komik yang mengandung pesan-pesan dan dapat dikaitkan dengan materi pembelajaran salah satunya adalah komik cerita rakyat. Mengingat agar tidak hilangnya cerita rakyat yang mengandung pesan-pesan yang sangat bermanfaat bagi penerus bangsa, sesuai dengan pendapat Sumayang (2017) sebagai genre sastra lisan cerita rakyat memiliki manfaat yang banyak bagi siswa maupun masyarakat pendukungnya. Maka diperlukanlah suatu media untuk melestarikan cerita rakyat tersebut yaitu berupa komik. Komik cerita rakyat ini nantinya akan bisa menjadi bahan bacaan untuk meningkatkan literasi seseorang terutama siswa.

Pengembangan komik agar bisa menghasilkan sebuah produk yang mendapat penilaian valid dan dinyatakan layak dari segi desain dan bahasa maka, harus melalui tahap-tahap pengembangan sesuai prosedur pengembangan. Penelitian pengembangan ini menggunakan model Four-D yang memiliki 4 tahapan yaitu: define (pendefinisian), design (perancangan), develop (pengembangan) dan disseminate (penyebaran).

Penelitian ini diawali dengan tahap define (pendefinisian), pada tahap ini yang dilakukan peneliti yaitu analisis awal dan analisi cerita. Pada analisis awal ini peneliti menganalisis cerita rakyat Rokan Hulu tepatnya di Desa Muara Rumbai. Salah satu cerita rakyatnya adalah asal usul Sungai Sorai. Cerita rakyat "Asal Usul Sungai Sorai” ini diketahui setelah membaca digital book "Lagenda Sungai Tapung Kumpulan Cerita Rakyat Rokan Hulu” penerbit Dr. Dendy Sugono. Analisis cerita dilakukan peneliti setelah mengetahui cerita dari digital book dan wawancara kepada narasumber.

Tahap kedua adalah tahap perancangan (design), pada tahap ini dilakukan dengan merancang bagaimana penyajian komik cerita rakyat asal usul Sungai Sorai yang disesuaikan dengan digital book dan wawancara narasumber. Pada tahap perancangan komik dilakukan kegiatan tulis dialog sesuai dengan cerita yang telah didapatkan dari digital book dan wawancara narasumber, menentukan tokoh/karakter yang digunakan yaitu Mak Sorai, 6 orang anak laki-laki Mak Sorai dan penduduk, serta tahap perancangan gambar komik yang menggunakan gambar manual sebagai pola yang kemudian agar komik menjadi menarik dengan berbagai warna digunakan aplikasi Autodesk SketchBook. Sejalan dengan pendapat Lubis, Mutia \& Isma (2017) komik merupakan sajian yang di dalamnya terdapat cerita maupun gambar-gambar dengan dilengkapi beberapa karakter yang mendukung sikap positif.

Tahap ketiga adalah tahap pengembangan (develop), pada tahap ini peneliti melakukan validasi produk mengenai desain dan bahasa dari komik. Validator yang digunakan pada komik ini terdiri dari 5 orang dengan 1 orang ahli desain produk, 1 orang ahli bahasa produk, dan 3 orang validator praktisi. Berdasarkan hasil validasi ahli desain draft 1 komik cerita rakyat "Asal Usul Sungai Sorai" memperoleh persentase skor $65,18 \%$ dengan kategori valid. Hasil validasi ahli desain draft 2 komik cerita rakyat "Asal Usul Sungai Sorai" memperoleh persentase skor 96,43\% dengan kategori sangat valid. Berdasarkan hasil validasi ahli bahasa draft 1 komik cerita rakyat "Asal Usul Sungai Sorai” memperoleh persentase skor 92,71\% dengan kategori sangat valid. Hasil validasi ahli bahasa draft 2 komik komik cerita rakyat "Asal Usul 
Sungai Sorai" memperoleh persentase skor $100 \%$ dengan kategori sangat valid. Berdasarkan hasil validasi praktisi terhadap desain komik cerita rakyat "Asal Usul Sungai Sorai" memperoleh persentase skor 97,03\% dengan kategori sangat valid. Dan berdasarkan hasil validasi praktisi terhadap bahasa komik cerita rakyat "Asal Usul Sungai Sorai" memperoleh persentase skor 96,53\% dengan kategori sangat valid. Perolehan hasil tersebut menandakan bahwa komik cerita rakyat "Asal Usul Sungai Sorai" yang dikembangkan peneliti sangat valid/layak digunakan pada siswa kelas V SD. Setelah melakukan validasi, selanjutnya dilakukan uji coba terbatas untuk mengetahui respon siswa terhadap komik cerita rakyat "Asal Usul Sungai Sorai" yang dikembangkan. Uji coba produk ini dilakukan kepada 10 orang siswa kelas V SD. Berdasarkan hasil data respon siswa terhadap komik cerita rakyat "Asal Usul Sungai Sorai" yang dikembangkan oleh peneliti diperoleh rata-rata persentase skor 98,04\% dengan kategori sangat baik. Hasil respon tersebut secara keseluruhan menandakan bahwa komik cerita rakyat "Asal Usul Sungai Sorai” yang dikembangkan oleh peneliti mendapat respon yang sangat baik dari siswa. Dilakukan juga tes tertulis yang terdiri dari 10 soal objektif tentang komik cerita rakyat "Asal Usul Sungai Sorai" untuk mengetahui pengetahuan dan pemahaman siswa. Berdasarkan hasil tes tertulis siswa diperoleh persentase skor $91 \%$ dengan kategori sangat baik. Hasil tes tersebut menandakan bahwa siswa sangat baik dalam memahami komik cerita rakyat "Asal Usul Sungai Sorai”.

Tahap terakhir adalah tahap penyebaran (disseminate), pada tahap ini dilakukan dengan cara FGD (Focus Group Discussion) atau diskusi kelompok terfokus dengan beberapa ahli. FGD adalah suatu proses pengumpulan data yang dimaksudkan untuk memperoleh data dan informasi dari suatu kelompok berdasarkan hasil diskusi yang terpusat pada suatu permasalahan tertentu (Aswat, 2019). FGD ini dilakukan peneliti dengan 5 orang guru yang ada di SD Negeri 002 Rambah Hilir. Hal yang didiskusikan pada tahap FGD ini adalah cerita rakyat "Asal Usul Sungai Sorai" yang dikembangkan oleh peneliti.

\section{PENUTUP}

Hasil penelitian dan pembahasan dapat disimpulkan bahwa: Pengembangan komik cerita rakyat "Asal Usul Sungai Sorai" untuk siswa kelas V SD dengan metode Research and Development dengan menggunakan model Four-D yang memiliki 4 tahap utama yaitu, Define (pendefinisian), Design (perancangan), Develop (pengembangan) dan Disseminate (penyebaran).

Penilaian validator ahli desain, validator ahli bahasa dan validator praktisi terhadap komik cerita rakyat "Asal Usul Sungai Sorai" memperoleh penilaian ahli desain pada draft 1 dengan persentase 65,18\% kategori valid meningkat pada draft 2 menjadi 96,43\% dengan kategori sangat valid. Hasil penilaian ahli bahasa pada draft 1 dengan persentase $92,71 \%$ kategori sangat valid dan meningkat pada draft 2 menjadi $100 \%$ dengan kategori sangat valid. Maka komik layak untuk diuji cobakan. Hasil uji coba produk terbatas komik cerita rakyat "Asal Usul Sungai Sorai" memperoleh persentase skor 98,04\% dengan kategori sangat baik, maka diketahui bahwa produk mendapat respon yang sangat baik dari siswa. Dilakukan juga tes pengetahuan dan pemahaman siswa terhadap komik cerita rakyat "Asal Usul Sungai Sorai" yang memperoleh persentase $91 \%$ dengan kategori sangat baik, maka diketahui pengetahuan dan pemahamn siswa sangat baik terhadap komik. 


\section{DAFTAR PUSTAKA}

Aswat,H. (2019). Efektivitas Pelaksanaan Metode Diskusi Kelompok Terpusat (Focus Group Discussion)Terhadap Motivasi Belajar IPS Murid Kelas V SD Negeri II Bone-Bone Kota Baubau. PERNIK Jurnal PAUD, 2(1). 1-11.

Hidayah, N. (2017). Pengembangan Media Pembelajaran Berbasis Komik pada Mata Pelajaran Ilmu Pengetahuan Sosial Kelas IV MI Nurul Hidayah Roworejo Negerikaton Pesawaran. Jurnal Pendidikan dan Pembelajaran Dasar. Jurusan PGMI Fakultas Tarbiyah dan Keguruan UIN Raden Intan, Lampung. 4(1), 3446.

Lubis, M. A., Mutia, S., \& Isma, Y. (2017). Kualitas Bahan Ajar Komik dalam Tingkat Pemahaman Belajar Peserta Didik. Prosiding Seminar Nasional Tahunan Fakultas Ilmu Sosial Universitas Negeri Medan, hlm. 45-50.

Maulida, N. (2018). Pengembangan Bahan Bacaan Cerita Bergambar Berorientasi Pendidikan Karakter Untuk Pembelajaran Membaca Siswa Kelas II SD. Lingua Franca: Jurnal Bahasa, Sastra, dan Pengajarannya, 6(1), 12-21.

McCloud, S. (1994). Understanding Comics The Invisible Art. America: A Kitchen Sink Press.

Ramadan, Z. H., Kurniaman, O., \& Noviana, E. (2013). Kompetensi Guru Sekolah Dasar Negeri dalam Memahami Media Pembelajaran Se-Kecamatan Tampan Kota Pekanbaru (Penelitian Survey Guru SDN Se-Kecamatan Tamapan Kota Pekanbaru). Jurnal IDEALIS, 1(1), 1-9.

Romario, N., \& Lakoro, R. (2014). Perencanaan Komik Aksi Fantasi Cerita Rakyat Malin Kundang. Jurnal SAINS dan Seni POMITS. Jurusan Desain Produk Industri, Fakultas Teknik Sipil dan Perencanaan, Institut Teknologi Sepuluh Nopember (ITS), Surabaya. 3(1), F-19-F-23.

Sugiyono. (2018). Metode Penelitian Kuantitatif, Kualitatif, dan R\&D. Bandung: Alfabeta

Sugono, D. (2008). Lagenda Sungai Tapung Kumpulan Cerita Rakyat Rokan Hulu. Pekanbaru: Balai Bahasa Provinsi Riau.

Sumayana, Y. (2017). Pembelajaran Sastra di Sekolah Dasar Berbasis Kearifan Lokal (Cerita Rakyat). Mimbar Sekolah Dasar, 4(1), 21-28.

Utariyanti, I. F. Z., Wahyuni, S., \& Zaenah, S. (2015). Pengembangan Media Pembelajaran Berbasis Komik dalam Materi Sistem Pernapasan pada Siswa Kelas VIII MTs Muhammadiyah 1 Malang. Jurnal Pendidikan Biologi Indonesia, 1(3), 343-355. 